\title{
AN ANALYSIS OF FACTOR THAT INFLUENCE THE LEVEL OF KNOWLEDGE OF SMES ABOUT ACCOUNTING OF SMES (A CASE STUDI AT SMES IN SUBANG REGENCY)
}

Virly Ramdhani ${ }^{1}$, Sri Mulyati ${ }^{2}$, Trisandi Eka Putri ${ }^{3}$

Sekolah Tinggi Ilmu Ekonomi Sutaatmadja

\begin{tabular}{l} 
INFO ARTIKEL \\
\hline Histori Artikel : \\
Tgl. Masuk : 04 Mei 2019 \\
Tgl. Diterima : 01 Juni 2019 \\
Tersedia Online 30 Juni 2019 \\
\hline Keywords: \\
Factors influencing \\
knowledge, Education, \\
Information / Mass Media, \\
Social Environment and \\
Cultural Environment, \\
Economy, Experience, \\
Age, SAK EMKM, \\
Accounting of SMEs
\end{tabular}

ABSTRAKIABSTRACT small and medium enterprises (SMEs), so some opinion state that small and medium enterprises (SMEs) are able to increase nation's economic system from both income and employment. Institute of Indonesia Chartered Accountants created a new Financial Accounting Standards (FAS) to facilitate SMEs in making financial reports that SAK EMKM (Micro Small and Medium Entities) made more simple than SAK ETAP.

The research method undertaken by the author in this paper is quantitative descriptive method using multiple linear regression analysis tool, the survey was conducted to 100 respondents of SMEs in Subang district. The data used are ordinal and interval data. Statistical methods for testing the data author used the SPSS 22 program.

By using multiple linear regression analysis obtained equation $Y=2,189+0,091 X 1$ $+0,031 X 2+0,418 X 3+0,163 X 4-0,047 X 5+$ $0,004 X 6+e$. From the research result, it is known that social environment and cultural environment and economic variables have significant effect to knowledge level of Accounting of SMEs, while education, information / mass media, experience, and age variables have no effect on knowledge level of Accounting of SMEs. These variables simultaneously affect the knowledge level of Accounting of SMEs. 


\section{PENDAHULUAN}

Perekonomian di Indonesia didominasi oleh sektor usaha kecil menengah (UKM), sehingga beberapa pendapat menyatakan bahwa usaha kecil menengah (UKM) mampu meningkatkat sistem perekonomian negara baik dari pendapatan maupun lapangan kerja. Tahun 2012 Usaha Mikro, Kecil dan Menengah (UMKM) di Indonesia mencapai 56,5 juta unit, menyumbang $59 \%$ pendapatan dari PDB dan menampung 97,16\% tenaga kerja. Sedangkan pada tahun 2013 Usaha Mikro, Kecil dan Menengah (UMKM) di Indonesia hampir mencapai 58 juta unit, menyumbang $60,34 \%$ pendapatan dari PDB dan menampung hampir $97 \%$ tenaga kerja (http://www.depkop.go.id/beritainformasi/data-informasi/data-umkm/, 2018).

Data jumlah Usaha Mikro, Kecil dan Menengah (UMKM) di Kabupaten Subang diperoleh dari Dinas Koperasi dan Usaha Mikro, Kecil dan Menengah (UMKM) Kabupaten Subang 2014 sampai 2017 adalah sebagai berikut:

Berdasarkan tabel 1.1 di atas dapat dilihat bahwa jumlah Usaha

\begin{tabular}{|c|c|c|c|c|}
\hline \multirow{2}{*}{ UMKM } & \multicolumn{4}{|c|}{ Tahun } \\
\cline { 2 - 5 } & $\mathbf{2 0 1 4}$ & $\mathbf{2 0 1 5}$ & $\mathbf{2 0 1 6}$ & $\mathbf{2 0 1 7}$ \\
\hline $\begin{array}{c}\text { Usaha } \\
\text { Mikro }\end{array}$ & 6.581 & 17.676 & 3.407 & 23.788 \\
\hline $\begin{array}{c}\text { Usaha } \\
\text { Kecil }\end{array}$ & 121 & 3.521 & 545 & 4.302 \\
\hline $\begin{array}{c}\text { Usaha } \\
\text { Menengah }\end{array}$ & 1 & 882 & 81 & 1.146 \\
\hline Total & $\mathbf{6 . 7 0 3}$ & $\mathbf{2 2 . 0 7 9}$ & $\mathbf{4 . 0 3 3}$ & $\mathbf{2 9 . 2 3 6}$ \\
\hline
\end{tabular}

Mikro, Kecil dan Menengah (UMKM) di Kabupaten Subang pada tahun 2014 sebanyak 46.703 unit dan terus meningkat hingga pada tahun 2017 sebanyak 29.236 unit. Tingkat usaha tertinggi setiap tahunnya diduduki oleh sektor perdagangan, sedangkan tingkat usaha terendah setiap tahunnya diduduki oleh sektor industri non pertanian. Seperti halnya Usaha Mikro, Kecil dan Menengah (UMKM) di tingkat Nasional maupun Jawa Barat, Usaha Mikro, Kecil dan Menengah (UMKM) di Kabupaten Subang juga terus meningkat sehingga memberikan dampak yang baik bagi penyerapan tenaga kerja dan pertumbuhan ekonomi di Kabupaten Subang.

Menurut Kukuh, saat ini bentuk laporan keuangan Usaha Mikro, Kecil dan Menengah (UMKM) dan koperasi yaitu Standar Akuntansi Keuangan 
Entitas Tanpa Akuntabilitas Publik (SAK ETAP) yang dirasa sulit. Sebagai solusinya, Ikatan Akuntan Indonesia (IAI) menyusun standar laporan keuangan yang lebih mudah dan sederhana. "Standar Akuntansi Keuangan (SAK) yang baru dibuat IAI adalah SAK EMKM (Entitas Mikro Kecil dan Menengah) yang dibuat lebih simpel daripada SAK ETAP yang akan diberlakukan pada awal tahun 2018 nanti," tambah Kaprodi Akuntansi STIE Indonesia Malang (https://malang.memo-

x.com/34925/sak-emkm-lebih-cocokbagi-umkm.html, 2017).

\section{Dalam menerapakan} pencatatan akuntansi sesuai Standar Akuntansi Keuangan Entitas Mikro, Kecil, dan Menengah (bagi Usaha Mikro, Kecil dan Menengah) pemilik maupun manajer harus mengetahui bagaimana perlakuan akuntansi dalam SAK EMKM tersebut. Pengetahuan dari pemilik maupun manajer setiap Usaha Mikro, Kecil dan Menengah (UMKM) tentu saja berbeda tergantung dari faktor-faktor yang mempengaruhinya. Faktor yang mempengaruhi tingkat pengetahuan dalam penelitian ini yaitu pendidikan, informasi/media massa, lingkunga sosial dan lingkungan budaya, ekonomi, pengalaman, dan usia.

Berdasarkan uraian latar belakang di atas, maka tujuan dari penelitian ini yaitu apakah faktor pendidikan, informasi/media massa, lingkungan sosial dan lingkungan budaya, ekonomi, pengalaman, dan usia berpengaruh terhadap tingkat Pengetahuan Pelaku UMKM mengenai Akuntansi UMKM baik secara parsial maupun simultan. Dengan menggunakan metode penelitiannya yaitu penelitian kuantitatif dan sampel pada penelitian ini adalah pelaku UMKM di Kab. Subang.

\section{KERANGKA TEORITIS DAN PENGEMBANGAN HIPOTESIS}

Pengetahuan

menurut Notoatmodjo (139:2007) : "merupakan hasil dari tahu, dan ini terjadi setelah orang melakukan penginderaan terhadap suatu objek tertentu." Penginderaan terjadi melalui pancaindra manusia, yakni indra penglihatan, pendengaran, penciuman, rasa, dan raba. Sebagian besar pengetahuan manusia diperoleh melalui mata dan telinga. Faktor yang 
mempengaruhi tingkat pengetahuan yaitu pendidikan; informasi/media massa; sosial, budaya, dan ekonomi; lingkungan; pengalaman; dan usia.

Hal tersebut menyebabkan
pengetahuan setiap orang akan
berbeda bagaimana seseorang
memperoleh pengetahuannya ataupun
faktor yang dapat mempengaruhi
pengetahuannya. Seperti halnya
seorang pemilik maupun manajer
suatu usaha memiliki pengetahuan
berbeda mengenai pencatatan
akuntansi khususnya SAK EMKM.
America Accounting Association dalam
Soemarso S.R (2004) mendefinisikan
akuntansi sebaga
mengidentifikasi, meses mokur, dan
melaporkan informasi ekonomi, untuk
memungkinkan adanya penilaian dan
keputusan yang jelas dan tegas bagi
mereka yang menggunakan informasi
tersebut”

SAK EMKM yang ditetapkan sebagai standar laporan keuangan bagi UMKM di Indonesia pada 1 Januari 2018. SAK EMKM dimaksudkan untuk digunakan oleh entitas mikro, kecil, dan menengah. Entitas mikro, kecil, dan menengah adalah entitas tanpa akuntabilitas publik yang signifikan, sebagaimana didefinisikan dalam Standar Akuntansi Keuangan Entitas Tanpa Akuntabilitas Publik (SAK ETAP), yang memenuhi definisi dan kriteria usaha mikro, kecil, dan menengah sebagaimana diatur dalam peraturan perundang-undangan yang berlaku di Indonesia, setidaktidaknya selama dua tahun berturutturut (Ikatan Akuntan Indonesia, 2016).

\section{Pengaruh Informasi/Media Massa terhadap Tingkat Pengetahuan Akuntansi}

Pendidikan adalah suatu usaha untuk mengembangkan kepribadian dan kemampuan di dalam dan di luar sekolah dan berlangsung seumur hidup. Pendidikan mempengaruhi proses belajar, makin tinggi pendidikan seorang makin mudah orang tersebut untuk menerima informasi. Dengan pendidikan tinggi maka seseorang akan cenderung untuk mendapatkan informasi, baik dari orang lain maupun dari media massa. Semakin banyak informasi yang masuk semakin banyak pula pengetahuan yang didapat (Notoatmodjo, 2007). 
Penelitian Debbianita dan Dewi (2016) menyebutkan bahwa terdapat perbedaan tingkat pengetahuan SAK ETAP pada pelaku UMKM yang memiliki tingkat pendidikan yang berbeda di mana pelaku UMKM yang tingkat pendidikannya $\mathrm{S} 1$ atau lebih memiliki tingkat pengetahuan yang lebih tinggi dibandingkan dengan pelaku UMKM yang tingkat pendidikannya di bawah S1. Hal ini dapat disebabkan oleh pola pemikiran yang berbeda pada pelaku UMKM yang tingkat pendidikannya rendah sehingga yang mereka utamakan hanya cara untuk mendapatkan keuntungan sebesar-besarnya tanpa memperhatikan cara pencatatan dalam laporan keuangan.

$\mathrm{H} 1$ : Pendidikan berpengaruh terhadap pengetahuan Akuntansi UMKM

\section{Pengaruh Informasi/Media Massa terhadap Tingkat Pengetahuan} Akuntansi UMKM

Informasi yang diperoleh baik dari pendidikan formal maupun non formal dapat memberikan pengaruh jangka pendek (immediate impact) sehingga menghasilkan perubahan atau peningkatan pengetahuan. Majunya teknologi akan tersedia bermacam-macam media massa yang dapat mempengaruuhi pengetahuan masyarakat tentang inovasi baru. Sebagai sarana komunikasi, berbagai bentuk media massa seperti televisi, radio, surat kabar, majalah dan lainlain mempunyai pengaruh besar terhadap pembentukan opini dan kepercayaan orang (Notoatmodjo, 2007)

Menurut Gurevitch (1990: 270) menjelaskan media massa sebagai berikut:

Media komunikasi massa atau media massa memiliki peranan yaitu sebagai alat kontrol sosial politik yang dapat memberikan berbagai informasi mengenai penyimpangan sosial itu sendiri baik yang dilakukan pemerintah, swasta maupun pihak masyarakat.Peran media sangatlah penting karena mampu menambah pengetahuan masyarakat mengenai isu-isu yeng terjadi baik di dalam negeri maupun luar negeri. (https://www.hipwee.com/opini/peranmedia-massa-dalam-penyebaraninformasi/) 


\section{H2 : Informasi/media massa berpengaruh terhadap pengetahuan Akuntansi UMKM \\ Pengaruh Lingkungan Sosial dan Budaya terhadap Tingkat Pengetahuan Akuntansi UMKM}

Menurut Notoatmodjo (2007) : "Lingkungan adalah segala sesuatu yang ada di sekitar individu, baik lingkungan fisik, biologis, maupun social." Lingkungan berpengaruh terhadap proses masuknya pengetahuan ke dalam individu yang berada dalam lingkungan tersebut. Hal ini terjadi karena adanya interaksi timdal balik ataupun tidak yang akan direspon sebagai pengetahuan oleh setiap individu.

Menurut Notoatmodjo (2007) : "Kebiasaan dan tradisi yang dilakukan orang-orang tanpa melalui penalaran apakah yang dilakukan baik atau buruk." Dengan hanya melihat atau mendengar suatu hal dari seseorang saja akan bertambah pengetahuannya walaupun tidak melakukan hal tersebut. Menurut Hofstede dalam Shvoong : "budaya adalah pemrograman kolektif atas pikiran yang membedakan anggota-anggota suatu kategori orang dari kategori lainnya."

Dari uiraian teori dan penelitian terdahulu dapat disimpulkan bahwa lingkungan sosial dan lingkungan budaya berpengaruh terhadap pengetahuan seseorang.

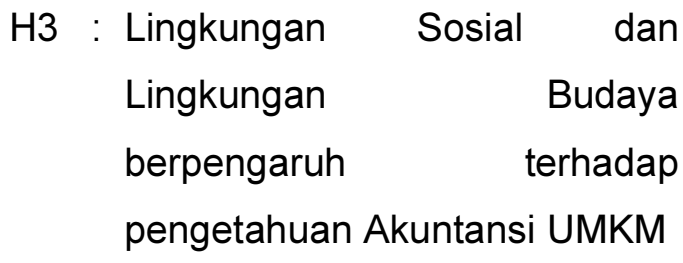

\section{Pengaruh Ekonomi terhadap Tingkat Pengetahuan Akuntansi UMKM}

Menurut Notoatmodjo (2007) : "Status ekonomi seseorang juga akan menentukan tersediannya suatu fasilitas yang diperlukan untuk kegiatan tertentu, sehingga status ekonomi ini akan mempengaruhi pengetahuan seseorang." Ekonomi merupakan salah satu ilmu sosial yang mempelajari aktivitas manusia yang berhubungan dengan produksi, distribusi, dan konsumsi terhadap barang dan jasa. Kata "ekonomi" merupakan kata serapan dari bahasa Yunani Kuno yang bermakna "pengelolaan rumah tangga". 
(http://id.m.wikipedia.org/

wiki/Ekonomi, 2018).

Abraham

Maslow

mengemukakan pendapat mengenai ekonomi sebagai berikut:

Ekonomi ialah bidang keilmuan yang dapat menyelesaikan permasalahan kehidupan manusia lewat penggemblengan seluruh sumber ekonomi yang memang dianggap efisien dan efektif.

(http://www.sekolahpendidikan.com /2017/03/pengertian-ekonomi-istilahumum-kbbi-bahasa-wikipediapendapat-para-ahli.htm|\#, 2018)

Dengan demikian ekonomi sangat berpengaruh terhadap pengetahuan seseorang, karena ekonomi dapat menunjang fasilitas untuk mendapatkan pengetahuan.

H4 : Ekonomi berpengaruh terhadap pengetahuan Akuntansi UMKM

Pengaruh Pengalaman terhadap Tingkat Pengetahuan Akuntansi UMKM

Menurut Notoatmodjo (2007) : "Pengalaman sebagai sumber pengetahuan adalah suatu cara untuk memperoleh kebenaran pengetahuan dengan cara mengulangi kembali pengetahuan yang diperoleh dalam memecahkan masalah yang dihadapi masa lalu." Pengalaman belajar dalam bekerja yang dikembangkan memberikan pengetahuan dan keterampilan professional serta pengalaman belajar selama bekerja akan dapat mengembangkan kemampuan mengambil keputusan yang merupakan manifestasi dari keterpaduan menalar secara ilmian dan etik yang bertolak dari masalah dalam bidang kerjanya.

Menurut Vardiansyah (2008:3) pengalaman adalah sebagai berikut: "Pengalaman ialah hasil persentuhan alam dengan panca seseorang indra manusia." Berasal dari kata pengalam-an. Pengalaman memungkinkan menjadi tahu dan hasil tahu ini kemudian disebut pengetahuan.

H5 : Pengalaman berpengaruh terhadap pengetahuan Akuntansi UMKM

\section{Pengaruh Usia terhadap Tingkat} Pengetahuan Akuntansi UMKM

Menurut Cuwin (2009) dalam Asta Kartika et al (2014) : "usia mempengaruhi terhadap daya tangkap 
dan pola pikir seseorang." Semakin bertambah usia akan semakin berkembang pula daya tangkap pola pikirnya, sehingga pengetahuan yang dipikirnya, sehingga pengetahuan yang diperolehnya semakin membaik.

Menurut Notoatmodjo (2007) usia dapat dijelaskan sebagai berikut:

Pada usia madya, individu akan lebih berperan aktif dalam masyarakat dan kehidupan sosial serta lebih banyak melakukan persiapan demi suksesnya upaya menyesuaikan diri menuju usia tua, selain itu orang usia madya akan lebih banyak menggunakan banyak waktu untuk membaca. Kemampuan intelektual, pemecahan masalah, dan kemampuan verbal dilaporkan hampir tidak ada penurunan pada usia ini.

H6 : Usia berpengaruh terhadap pengetahuan Akuntansi UMKM

\section{Pengaruh}

Pendidikan, Informasi/Media Massa, Lingkungan Sosial dan Lingkungan Budaya, Ekonomi, Pengalaman dan Usia terhadap Tingkat Pengetahuan Akuntansi UMKM
Menurut Notoatmodjo (2007) faktor-faktor yang mempengaruhi pengetahuan yaitu : "pendidikan, Informasi/Media Massa, Sosial, Budaya, Ekonomi, Lingkungan, Pengalaman dan Usia." Seperti yang telah dijelaskan sebelumnya yang didukung oleh teori dan penelitian terdahulu, maka variabel pendidikan, informasi/media massa, lingkungan sosial dan lingkungan budaya, ekonomi, pengalaman dan usia berpengaruh secara simultan terhadap pengetahuan seseorang.

$\mathrm{H} 7$ : Pengaruh Pendidikan, Informasi/Media Massa, lingkungan Sosial dan lingkungan Budaya, Ekonomi, Pengalaman dan Usia berpengaruh positif terhadap pengetahuan Akuntansi UMKM

\section{METODOLOGI PENELITIAN}

Populasi penelitian ini adalah UMKM di Kabupaten Subang. Sampel yang dipilih dengan menggunakan teknik purposive sampling yang dipilih karena karakteristik tertentu. Jumlah sampel yang dalam penelitian ini minimal yaitu 100 responden.Penelitian ini menggunakan penelitian kuantitatif 


dengan cara survey melalui
penyebaran kuesioner kepada
responden.

\section{HASIL DAN PEMBAHASAN}

Dalam melakukan penelitian dengan cara kuesioner dengan responden yang dijadikan objek penelitian ini

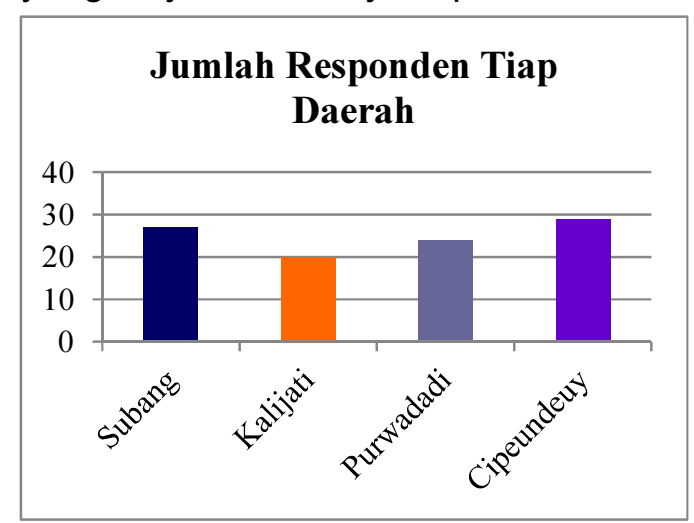
adalah para pelaku UMKM di Kab. Subang, dengan pemilihan lokasi pada wilayah pusat kota Subang dan Subang bagian Barat. Pemilihan lokasi tersebut dikarenakan banyaknya industri besar seperti perusahaan tekstil, otomotif, dan sebagainya yang terletak di wilayah Subang bagian Barat serta daya tarik pusat kota Subang sebagai wisata maupun pusat belanja. Banyaknya perusahaan dan daya tarik wisata di wilayah tersebut mengakibatkan banyaknya masyarakat atau pendatang yang bekerja di perusahaan-perusahaan tersebut. Dengan banyaknya masyarakat di wilayah Subang bagian Barat dan daya tarik wisata dapat menjadi peluang bagi para pelaku UMKM untuk memasarkan produknya. Berikut adalah frekuensi jumlah responden dari setiap daerah:

Gambar di atas dapat diketahui jumlah responden dari tiap daerah yaitu Subang sebanyak 27 orang responden, Kalijati sebanyak 20 orang responden, Purwadadi sebanyak 24 orang responden, dan Cipeundeuy sebanyak 29 orang responden. Karakteristik responden mengenai

\section{Jenis Kelamin}

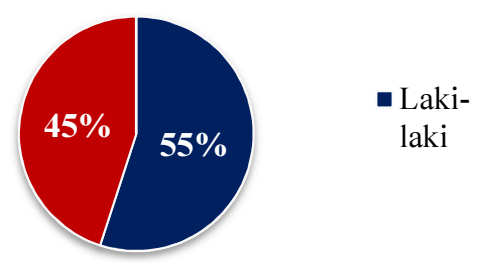

jenis kelamin dapat dilihat secara ringkas pada grafik berikut ini:

Berdasarkan gambar menunjukan bahwa dari 100 responden 55\% responden berjenis kelamin laki-laki, sedangkan $45 \%$ berjenis kelamin perempuan.

\section{Uji Validitas}


Hasil uji validitas untuk Untuk rincian hasil pengujian variabel kuesioner dengan $\mathrm{df}=100-2=98$ $\mathrm{X}_{5}$ adalah sebagai berikut: pada tingkat signifikansi (a) sebesar $5 \%$ atau 0,05 diperoleh nilai $r$ tabel $=$ 0,197 bahwa item-item kuesioner memiliki nilai $r$ hitung lebih besar dari $r$ tabel dan nilai positif sebagaimana yang telah ditetapkan di atas. Hal ini menunjukan bahwa item-item sudah valid.

Pengujian Validitas Lingkungan Sosial dan Lingkungan Budaya $\left(\mathrm{X}_{3}\right)$. Pengujian validitas untuk kuesioner lingkungan sosial dan lingkungan budaya $\left(\mathrm{X}_{3}\right)$ yang terdiri dari 6 butir pernyataan. Hasil pengujian menunjukkan bahwa salah satu pernyataan untuk kuesioner variabel $\mathrm{X}_{3}$ ada yang tidak valid, karena memiliki nilai $r$ hitung yang kurang dari $r$ tabel. Artinya salah satu item yang tidak valid tersebut tidak dapat digunakan. Pengujian validitas untuk kuesioner pengalaman $\left(X_{5}\right)$ yang terdiri dari 5 butir pernyataan. Hasil pengujian menunjukkan bahwa semua pernyataan untuk kuesioner variabel $X_{5}$ sudah valid, karena memiliki nilai $r$ hitung positif dan lebih dari $r$ tabel. Artinya item-item tersebut dapat digunakan.

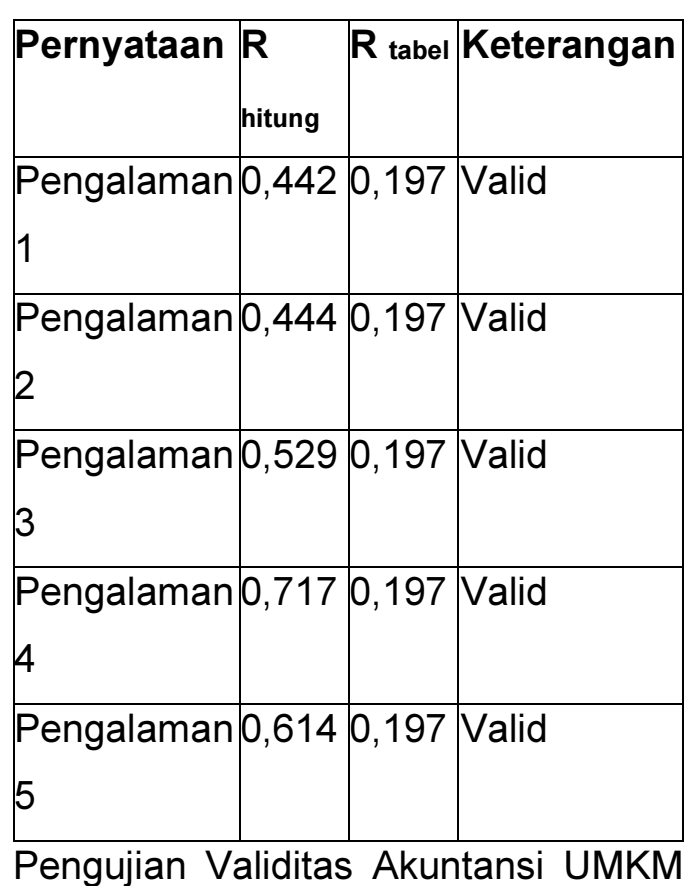

(Y)

Pengujian validitas untuk kuesioner Akuntansi UMKM (Y) yang terdiri dari 5 butir pernyataan. Hasil pengujian menunjukkan bahwa semua pernyataan untuk kuesioner variabel $Y$ sudah valid, karena memiliki nilai $r$ hitung positif dan lebih dari $r$ tabel. Artinya itemitem tersebut dapat digunakan. Untuk rincian hasil pengujian variabel $Y$ adalah sebagai berikut:

Pernyataan $R_{\text {hitung }} \mathbf{R}$ tabel Keterangan 


\begin{tabular}{|l|l|l|l|}
\hline $\begin{array}{l}\text { Akuntansi } \\
\text { UMKM 1 }\end{array}$ & 0,583 & 0,197 & Valid \\
\hline $\begin{array}{l}\text { Akuntansi } \\
\text { UMKM 2 }\end{array}$ & 0,541 & 0,197 & Valid \\
\hline $\begin{array}{l}\text { Akuntansi } \\
\text { UMKM 3 }\end{array}$ & $-0,683$ & 0,197 & Tidak Valid \\
\hline $\begin{array}{l}\text { Akuntansi } \\
\text { UMKM 4 }\end{array}$ & 0,599 & 0,197 & Valid \\
\hline $\begin{array}{l}\text { Akuntansi } \\
\text { UMKM 5 }\end{array}$ & 0,451 & 0,197 & Valid \\
\hline $\begin{array}{l}\text { Akuntansi } \\
\text { UMKM 6 }\end{array}$ & 0,447 & 0,197 & Valid \\
\hline $\begin{array}{l}\text { Akuntansi } \\
\text { UMKM 7 }\end{array}$ & 0,225 & 0,197 & Valid \\
\hline $\begin{array}{l}\text { Akuntansi } \\
\text { UMKM 8 }\end{array}$ & 0,413 & 0,197 & Valid \\
\hline $\begin{array}{l}\text { Akuntansi } \\
\text { UMKM 9 }\end{array}$ & 0,359 & 0,197 & Valid \\
\hline $\begin{array}{l}\text { Akuntansi } \\
\text { UMKM 10 }\end{array}$ & 0,450 & 0,197 & Valid \\
\hline
\end{tabular}

Sumber: Data diolah, 2018

\section{Uji Reliabilitas}

Suatu konstruk atau variabel dikatakan reliabel jika memberikan nilai Cronbach Alpha > 0,60 (Nunnaly, 1960 dalam Umiyati dan Nurmalasari, 2016:140). Adapun hasil dari pengujian. Berdasarkan tabel $4.4 \mathrm{di}$ atas menyatakan bahwa variabel lingkungan, pengalaman, dan Akuntansi UMKM ( $\mathrm{X}_{3}, \mathrm{X}_{5}$, dan $\left.\mathrm{Y}\right)$ memiliki status reliabel. $\mathrm{Hal}$ ini dikarenakan nilai Cronbach Alpha variabel tersebut lebih besar dari 0,6 kondisi ini juga memberikan arti bahwa seluruh variabel tersebut dapat digunakan pada analisis selanjutnya.

\section{Analisis Regresi Linear Berganda}

Analisis Regresi Linear Berganda digunakan untuk mengetahui bagaimana pengaruh Pendidikan $\left(\mathrm{X}_{1}\right)$, Informasi/Media Massa ( $\left.\mathrm{X}_{2}\right)$, Lingkungan Sosial dan Lingkungan Budaya (X) Ekonomi $\left(\mathrm{X}_{4}\right)$, Pengalaman $\left(\mathrm{X}_{5}\right)$ dan Usia $\left(\mathrm{X}_{6}\right)$ terhadap Pengetahuan SAK EMKM (Y). Hasil pengolahan data menggunakan SPSS dapat dilihat pada tabel berikut:

\section{Coefficients $^{a}$}

\begin{tabular}{|c|c|c|c|c|c|}
\hline \multirow{2}{*}{ Model } & \multicolumn{2}{|c|}{$\begin{array}{l}\text { Unstandar } \\
\text { dized } \\
\text { Coefficient } \\
\text { s }\end{array}$} & \begin{tabular}{l}
\multicolumn{1}{c}{ Stand } \\
ardized \\
Coeffici \\
ents
\end{tabular} & & \\
\hline & B & $\begin{array}{l}\text { Std. } \\
\text { Erro } \\
r\end{array}$ & Beta & $\mathrm{t}$ & Si \\
\hline $\begin{array}{c}1 \text { (Con } \\
\text { stan } \\
t)\end{array}$ & $\begin{array}{l}2.25 \\
9\end{array}$ & .345 & & $\begin{array}{l}6.5 \\
49\end{array}$ & $\begin{array}{l}.0 \\
00\end{array}$ \\
\hline
\end{tabular}




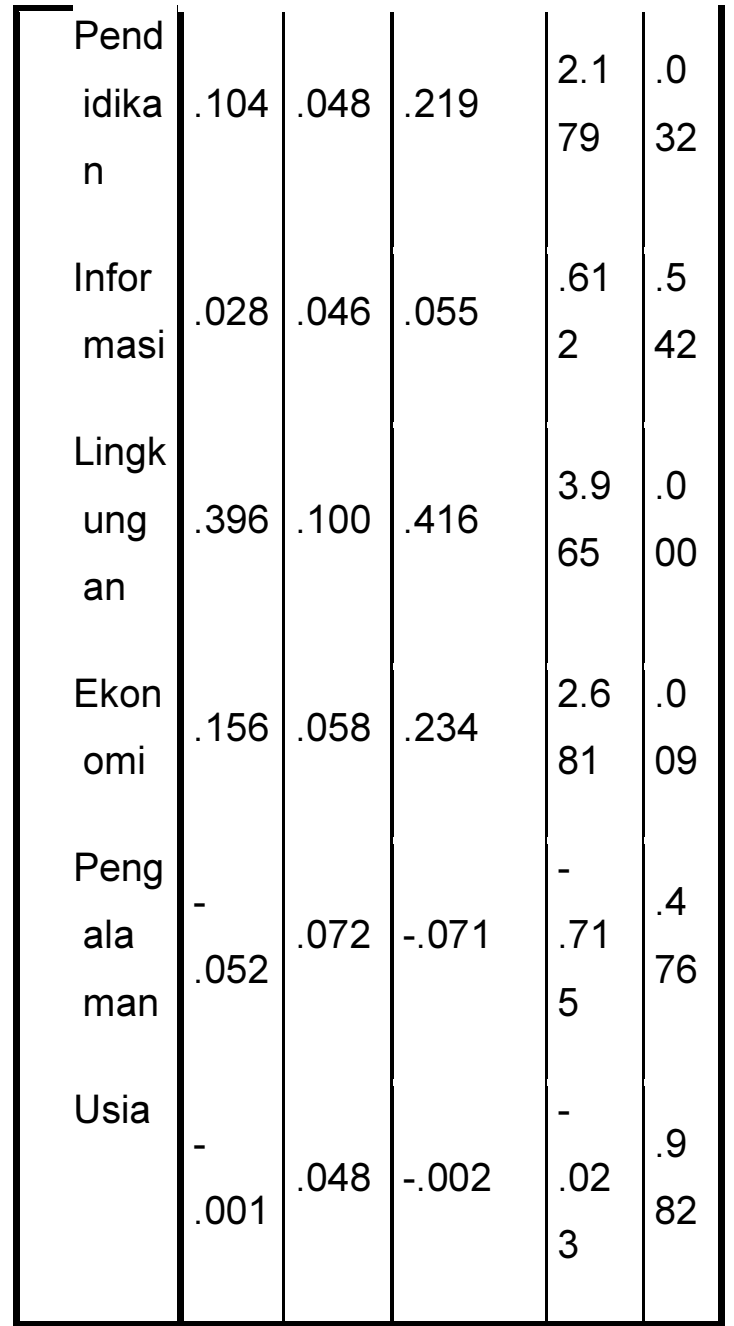

a. Dependent Variable: Akuntansi UMKM

Sumber: Data diolah, 2018

$$
\begin{aligned}
Y=2,259+0,104 X_{1}+0,028 X_{2} \\
+0,396 X_{3}+0,156 X_{4} \\
-0,052 X_{5}-0,001 X_{6}+e
\end{aligned}
$$

Model regresi tersebut dapat diinterpretasikan sebagai berikut:

1. Nilai 2,259 merupakan nilai konstanta ( $\alpha$ ) yang menunjukkan bahwa jika tidak ada persepsi pendidikan $\left(\mathrm{X}_{1}\right)$, Informasi/Media Massa $\left(X_{2}\right)$, Lingkungan Sosial dan Lingkungan Budaya $\left(X_{3}\right)$, Ekonomi $\left(X_{4}\right)$, Pengalaman $\left(X_{5}\right)$, dan Usia (X6), maka pengetahuan Akuntansi UMKM (Y) akan mencapai nilai sebesar 2,259.

2. Koefisien regresi $X_{1}$ (pendidikan) diperoleh sebesar 0,104. Hal ini menunjukkan bahwa persepsi pendidikan yang tinggi, maka pelaku UMKM dapat meningkatkan pengetahuan Akuntansi UMKM sebesar 0,104.

3. Koefisien regresi $\mathrm{X}_{2}$ (informasi/media massa) diperoleh sebesar 0,028. Hal ini menunjukkan bahwa persepsi informasi/media massa yang tinggi, maka pelaku UMKM dapat meningkatkan pengetahuan Akuntansi UMKM sebesar 0,028.

4. Koefisien regresi $X_{3}$ (lingkungan sosial dan lingkungan budaya) diperoleh sebesar 0,396. Hal ini menunjukkan bahwa persepsi lingkungan sosial dan lingkungan budaya yang tinggi, maka pelaku UMKM dapat meningkatkan 
pengetahuan Akuntansi UMKM sebesar 0,396.

5. Koefisien regresi $X_{4}$ (ekonomi) diperoleh sebesar 0,156. Hal ini menunjukkan bahwa persepsi ekonomi yang tinggi, maka pelaku UMKM dapat meningkatkan pengetahuan Akuntansi UMKM sebesar 0,156.

6. Koefisien regresi $X_{5}$ (pengalaman) diperoleh sebesar $-0,052$. Hal ini menunjukkan bahwa persepsi pengalaman yang rendah, maka pelaku UMKM dapat meningkatkan pengetahuan Akuntansi UMKM sebesar 0,052. Karena pengalaman yang mereka rasa kurang, maka jadi pemicu untuk mencari pengetahuan yang lebih banyak melalui faktor lain.

7. Koefisien regresi $X_{6}$ (usia) diperoleh sebesar $-0,001$. Hal ini menunjukkan bahwa persepsi usia yang rendah, maka pelaku UMKM dapat meningkatkan pengetahuan Akuntansi UMKM sebesar -0,001. Hal ini bisa terjadi karena semakin bertambah usia atau dalam hal ini lebih dari 41, maka ingatan yang dimiliki seseorang juga akan menurun.

\section{Uji Signifikansi Simultan (Uji Statistik F)}

Uji F dimaksudkan untuk mengetahui pengaruh variabel-variabel independen yaitu pendidikan, informasi/media massa, lingkungan sosial dan budaya, ekonomi, pengalaman, dan usia tehadap variabel dependen yaitu pengetahuan Akuntansi UMKM (Y) secara simultan atau untuk pengambilan keputusan apakah Ho ditolak atau Ha diterima mengenai pengaruh variabel independen terhadap variabel dependen secara simultan. Adapun hipotesis uji regresi adalah sebagai berikut:

$\mathrm{H}_{0}=$ Tidak terdapat pengaruh yang signifikan anatara persepsi pendidikan, informasi/media massa, lingkungan sosial dan budaya, ekonomi, pengalaman, dan usia terhadap pengetahuan Akuntansi UMKM

$\mathrm{H}_{\mathrm{a}}=$ Terdapat pengaruh yang signifikan anatara persepsi pendidikan, informasi/media massa, lingkungan sosial dan budaya,

ekonomi, 
pengalaman, dan usia $\mathrm{H}_{\mathrm{a}}$ diterima, artinya bahwa variabel terhadap pengetahuan Akuntansi UMKM

Dari hasil regresi telah diperoleh suatu bentuk persamaan sebagai berikut:

$$
\begin{aligned}
Y=2,259+0,104 X_{1}+0,028 X_{2} \\
+0,396 X_{3}+0,156 X_{4} \\
-0,052 X_{5}-0,001 X_{6}+e
\end{aligned}
$$

Apabila $F$ hitung $>F$ tabel dimana df1=k1=7-1=6 dan df2=n-k=100-7=93, maka Ho ditolak.

Dari hasil perhitungan menggunakan SPSS diperoleh nilainilai koefisien regresi mengenai pendidikan, informasi/media massa, lingkungan sosial dan budaya, ekonomi, pengalaman, dan usia serta pengetahuan Akuntansi UMKM pada pelaku UMKM di Kab. Subang sebagai berikut:

\section{Model Pengaruh Variabel Secara Simultan}

Hasil pengujian model keseluruhan diperoleh nilai $F$ sebesar 8,565 untuk $F$ tabel dengan $(\alpha=0,05)$ diperoleh nilai $F$ tabel $=2,200$ karena $F$ hitung $>\mathrm{F}$ tabel maka $\mathrm{H}_{0}$ ditolak sehingga 


\begin{tabular}{|c|c|c|c|c|c|}
\hline \multirow[b]{2}{*}{ Model } & \multicolumn{2}{|c|}{$\begin{array}{l}\text { Unstandard } \\
\text { ized } \\
\text { Coefficient } \\
\text { s }\end{array}$} & $\begin{array}{l}\text { Standa } \\
\text { rdized } \\
\text { Coeffic } \\
\text { ients }\end{array}$ & & \multirow{2}{*}{ Sig } \\
\hline & B & Error & Beta & $t$ & \\
\hline $\begin{array}{ll}1 & \text { (Co } \\
\text { nsta } \\
\text { nt) }\end{array}$ & $\begin{array}{l}2.25 \\
9\end{array}$ & .345 & & $\begin{array}{l}6.5 \\
49\end{array}$ & $\begin{array}{l}.00 \\
0\end{array}$ \\
\hline $\begin{array}{l}\text { Pen } \\
\text { didik } \\
\text { an }\end{array}$ & . 104 & .048 & 219 & $\begin{array}{l}2.1 \\
79\end{array}$ & $\begin{array}{l}.03 \\
2\end{array}$ \\
\hline $\begin{array}{l}\text { Infor } \\
\text { masi }\end{array}$ & .028 & .046 & . 055 & $\begin{array}{l}.61 \\
2\end{array}$ & $\begin{array}{l}.54 \\
2\end{array}$ \\
\hline $\begin{array}{l}\text { Ling } \\
\text { kung } \\
\text { an }\end{array}$ & .396 & .100 & .416 & $\begin{array}{l}3.9 \\
65\end{array}$ & $\begin{array}{l}.00 \\
0\end{array}$ \\
\hline $\begin{array}{l}\text { Eko } \\
\text { nomi }\end{array}$ & . 156 & .058 & .234 & $\begin{array}{l}2.6 \\
81\end{array}$ & $\begin{array}{l}.00 \\
9\end{array}$ \\
\hline $\begin{array}{l}\text { Pen } \\
\text { gala } \\
\text { man }\end{array}$ & .052 & .072 & -.071 & $\begin{array}{l}- \\
.71 \\
5\end{array}$ & $\begin{array}{l}.47 \\
6\end{array}$ \\
\hline Usia & $\begin{array}{l}- \\
.001\end{array}$ & .048 & -.002 & $\begin{array}{l}- \\
.02 \\
3\end{array}$ & \begin{tabular}{|l}
.98 \\
2
\end{tabular} \\
\hline
\end{tabular}

$=100$ adalah 1,986. Dari hasil perhitungan menggunakan SPSS diperoleh nilai $t$ hitung sebagai berikut: Hasil pengolahan tersebut dapat diinterpretasikan sebagai berikut:

1. Test Hipotesis Pengaruh Persepsi Pendidikan terhadap Pengetahuan Akuntansi UMKM

Dari hasil perhitungan dapat dilihat bahwa pendidikan memiliki taraf signifikansi 0,032 yakni kurang dari 0,05 dan $t$ hitung sebesar 2,179 > 1,986 Berdasarkan kriteria dapat diketahui bahwa $\mathrm{H}_{1}$ diterima, artinya pendidikan berpengaruh terhadap pengetahuan Akuntansi UMKM.

2. Test Hipotesis Pengaruh Persepsi Informasi/Media Massa terhadap Pengetahuan Akuntansi UMKM Dari hasil perhitungan dapat lihat bahwa informasi/media massa memiliki taraf signifikansi 0,542 yakni lebih dari 0,05 dan $t$ hitung sebesar $0,612<1,986$. Berdasarkan kriteria dapat diketahui bahwa $\mathrm{H}_{2}$ ditolak, artinya informasi/media massa tidak berpengaruh terhadap pengetahuan Akuntansi UMKM. 
3. Test Hipotesis Pengaruh Persepsi Lingkungan Sosial dan Lingkungan Budaya terhadap Pengetahuan Akuntansi UMKM

Dari hasil perhitungan dapat lihat bahwa lingkungan sosial dan lingkungan budaya memiliki taraf signifikansi 0,000 yakni kurang dari 0,05 dan $t$ hitung sebesar 3,965 > 1,986. Berdasarkan kriteria dapat diketahui bahwa $\mathrm{H}_{3}$ diterima, artinya lingkungan sosial dan lingkungan budaya berpengaruh terhadap pengetahuan Akuntansi UMKM.

4. Test Hipotesis Pengaruh Persepsi Ekonomi terhadap Pengetahuan Akuntansi UMKM

Dari hasil perhitungan didapat lihat bahwa ekonomi memiliki taraf signifikansi 0,009 yakni kurang dari 0,05 dan $t$ hitung sebesar $2.681>$ 1,986. Berdasarkan kriteria dapat diketahui bahwa $\mathrm{H}_{4}$ diterima, artinya ekonomi berpengaruh terhadap pengetahuan Akuntansi UMKM.

5. Test Hipotesis Pengaruh Persepsi Pengalaman terhadap Pengetahuan Akuntansi UMKM
Dari hasil perhitungan didapat lihat bahwa pengalaman memiliki taraf signifikansi 0,476 yakni lebih dari 0,05 dan $\mathrm{t}$ hitung sebesar $-0,715<$ 1,986. Berdasarkan kriteria dapat diketahui bahwa $\mathrm{H}_{5}$ ditolak, artinya pengalaman tidak berpengaruh terhadap pengetahuan Akuntansi UMKM.

6. Test Hipotesis Pengaruh Persepsi Usia terhadap Pengetahuan Akuntansi UMKM

Dari hasil perhitungan didapat lihat bahwa pengalaman memiliki taraf signifikansi 0,982 yakni lebih dari 0,05 dan $t$ hitung sebesar -0,023< 1,986. Berdasarkan kriteria dapat diketahui bahwa $\mathrm{H}_{6}$ ditolak, artinya usia tidak berpengaruh terhadap pengetahuan Akuntansi UMKM.

Analisis Koefisien Determinasi $\left(\mathbf{R}^{2}\right)$ Setelah melakukan analisis regresi dan diperoleh hasil pengujian signifikansi atau tidaknya, maka selanjutnya harus dihitung koefisien dterminasi untuk mengetahui besarnya pengaruh dari persepsi pendidikan $\left(X_{1}\right)$, informasi/media massa $\left(X_{2}\right)$, lingkungan sosial dan lingkungan budaya $\left(X_{3}\right)$, ekonomi $\left(X_{4}\right)$, pengalaman $\left(X_{5}\right)$, dan usia $\left(X_{6}\right)$ 
terhadap pengetahuan Akuntansi UMKM (Y). Untuk melihat hasil pengolahan koefisien determinasi menggunakan SPSS dapat dilihat pada tabel berikut:

Dari hasil pengolahan pada tabel 4.8 di atas dapat diketahui bahwa koefisien determinasi (Adjusted $\mathrm{R}^{2}$ ) yaitu sebesar $0,314 \times 100 \%=31,4 \%$, artinya bahwa pengetahuan Akuntansi UMKM dipengaruhi oleh pendidikan $\left(\mathrm{X}_{1}\right)$, informasi/media massa $\left(\mathrm{X}_{2}\right)$, lingkungan sosial dan lingkungan budaya $\left(\mathrm{X}_{3}\right)$, ekonomi $\left(\mathrm{X}_{4}\right)$, pengalaman $\left(X_{5}\right)$, dan usia $\left(X_{6}\right)$ sebesar $31,4 \%$ dan sisanya sebesar $68,6 \%$ dipengaruhi faktor pengetahuan Akuntansi UMKM lain yang tidak diteliti dalam penelitian ini.

\section{Pengaruh Pendidikan terhadap Pengetahuan Akuntansi UMKM}

Berdasarkan total jawaban kuesioner untuk Variabel $\mathrm{X}_{1}$ (Pendidikan) dari 100 responden didapat bahwa tingkat pendidikan terakhir pelaku UMKM Kab. Subang didominasi pada tingkat SMA dengan persentase $56 \%$ diikuti dengan tingkat SMP 20\%, S1 11\%, SD 8\%, dan D3 $5 \%$. Pada penelitian ini membuktikan adanya pengaruh pendidikan terhadap pengetahuan Akuntansi UMKM sejalan dengan hasil penelitian Debbianita dan Dewi (2016) menyebutkan bahwa terdapat perbedaan tingkat pengetahuan SAK ETAP pada pelaku UMKM yang memiliki tingkat pendidikan yang berbeda di mana pelaku UMKM yang tingkat pendidikannya $\mathrm{S} 1$ atau lebih memiliki tingkat pengetahuan yang lebih tinggi dibandingkan dengan pelaku UMKM yang tingkat pendidikannya di bawah S1.

Hasilnya dapat dilihat pada uji statistik $\mathrm{t}$ yang menunjukan bahwa taraf signifikansi lebih kecil dari 0,05 yaitu 0,032 yang berarti $\mathrm{H}_{1}$ diterima. Jadi Pendidikan berpengaruh terhadap Pengetahuan Akuntansi UMKM. Hal tersebut bisa terjadi karena Pendidikan mempengaruhi proses belajar, makin tinggi pendidikan seorang makin mudah orang tersebut untuk menerima informasi dalam hal pengetahuan mengenai akuntansi.

\section{Pengaruh Informasi/Media Massa terhadap Pengetahuan Akuntansi UMKM \\ Berdasarkan total jawaban kuesioner untuk Variabel $\mathrm{X}_{2}$}


(Informasi/Media Massa) dari 100 responden didapat bahwa banyak informasi/media massa yang dikonsumsi oleh pelaku UMKM Kab. Subang didominasi pada mengkonsumsi hanya 1 informasi/media massa dengan persentase $58 \%$ diikuti dengan mengkonsumsi 2 informasi/media massa $27 \%$, mengkonsumsi 3 informasi/media massa $11 \%$, mengkonsumsi 4 informasi/media massa $2 \%$, dan mengkonsumsi 5 informasi/media massa serta mengkonsumsi 6 informasi/media massa masing-masing 1\%. Pada penelitian ini tidak membuktikan adanya pengaruh informasi/media massa terhadap pengetahuan Akuntansi UMKM sejalan dengan hasil penelitian Rias Tuti dan S, Patricia Febrina Dwijayanti (2014) menyatakan dalam penelitiannya yaitu variabel pemberian informasi dan sosialisasi tidak berpengaruh terhadap pemahaman UMKM dalam menyusun laporan keuangan berdasarkan SAK ETAP.

Hasilnya dapat dilihat pada uji statistik t yang menunjukan bahwa nilai signifikansi lebih besar dari 0,05 yaitu
0,542 yang berarti $\mathrm{H}_{2}$ ditolak. Jadi Informasi/Media Massa tidak berpengaruh terhadap Pengetahuan Akuntansi UMKM. Hal tersebut bisa terjadi karena dengan kesibukan pelaku UMKM maka minat responden untuk menggali lebih banyak informasi mengenai akuntansi itu masih sedikit, sehingga mereka hanya menyempatkan menggali informasi mengenai akuntansi dengan mengkonsumsi 1 informasi/media massa saja.

\section{Pengaruh Lingkungan Sosial dan Lingkungan Budaya terhadap Pengetahuan Akuntansi UMKM}

Berdasarkan total jawaban kuesioner untuk Variabel $\mathrm{X}_{3}$ (Lingkungan Sosial dan Lingkungan Budaya) dari 100 responden didapat bahwa persepsi lingkungan sosial dan lingkungan budaya pelaku UMKM Kab. Subang memiliki persentase sebesar $77,2 \%$. Pada penelitian ini membuktikan adanya pengaruh lingkungan sosial dan lingkungan budaya terhadap pengetahuan Akuntansi UMKM sejalan dengan teori Notoatmodjo (2007) Lingkungan adalah segala sesuatu yang ada di sekitar individu, baik lingkungan fisik, 
biologis, maupun sosial. Lingkungan berpengaruh terhadap proses masuknya pengetahuan ke dalam individu yang berada dalam lingkungan tersebut. Hal ini terjadi karena adanya interaksi timdal balik ataupun tidak yang akan direspon sebagai pengetahuan oleh setiap individu.

Hasilnya dapat dilihat pada uji statistik t yang menunjukan bahwa nilai signifikansi lebih kecil dari 0,05 yaitu 0,000 yang berarti H3 diterima. Jadi Lingkungan Sosial dan Lingkungan Budaya berpengaruh terhadap Pengetahuan Akuntansi UMKM. Hal ini disebabkan karena lingkungan adalah tempat seseorang beraktifitas seharihari sehingga informasi akan sangat mudah menyebarkan di sekitarnya, dan menyebabkan informasi akan mudah diserap oleh seseorang melalui penjelasan langsung atau yang disebut mulut ke mulut.

\section{Pengaruh Ekonomi terhadap Pengetahuan Akuntansi UMKM}

Berdasarkan total jawaban kuesioner untuk Variabel $\mathrm{X}_{3}$ (Ekonomi) dari 100 responden didapat bahwa persepsi ekonomi pelaku UMKM Kab. Subang didominasi oleh Usaha Mikro dengan rata-rata persentase sebesar
73\%. diikuti dengan Usaha Kecil sebesar 23\% dan Usaha Menengah 4\%. Pada penelitian ini membuktikan adanya pengaruh ekonomi terhadap pengetahuan Akuntansi UMKM sejalan dengan teori Notoatmodjo (2007) Status ekonomi seseorang juga akan menentukan tersediannya suatu fasilitas yang diperlukan untuk kegiatan tertentu, sehingga status ekonomi ini akan mempengaruhi pengetahuan seseorang.

Hasilnya dapat dilihat pada uji statistik $t$ yang menunjukan bahwa nilai signifikansi lebih kecil dari 0,05 yaitu 0,009 yang berarti $\mathrm{H}_{4}$ diterima. Jadi Ekonomi berpengaruh terhadap Pengetahuan Akuntansi UMKM. Hal ini disebabkan karena dengan ekonomi merupakan salah satu faktor penting dalam menunjang kehidupan seharihari. Dengan memiliki perekonomian yang cukup atau lebih maka seseorang akan mudah memiliki fasilitas untuk menggali informasi lebih banyak pula.

Pengaruh Pengalaman terhadap Pengetahuan Akuntansi UMKM

Berdasarkan total jawaban kuesioner untuk Variabel $\mathrm{X}_{5}$ (Pengalaman) dari 100 responden didapat bahwa persepsi pengalaman 
para pelaku UMKM Kab. Subang memiliki persentase sebesar $78,4 \%$. Pada penelitian ini tidak membuktikan adanya pengaruh pengalaman terhadap pengetahuan Akuntansi UMKM bertolak belakang dengan teori Vardiansyah (2008:3) Pengalaman ialah hasil persentuhan alam dengan panca seseorang indra manusia. Berasal dari kata peng-alam-an. Pengalaman memungkinkan menjadi tahu dan hasil tahu ini kemudian disebut pengetahuan.

Hasilnya dapat dilihat pada uji statistik t yang menunjukan bahwa nilai signifikansi lebih besar dari 0,05 yaitu 0,476 yang berarti $\mathrm{H}_{5}$ ditolak. Jadi Pengalaman tidak berpengaruh terhadap Pengetahuan Akuntansi UMKM. Hal tersebut bisa terjadi karena pengalaman usaha yang mereka miliki masih baru dan latarbelakang keluarga mereka bukan pengusaha, sehingga pengetahuan yang mereka miliki masih sedikit. Hal itulah yang menjadi pemicu mereka untuk menggali informasi lebih banyak. Sehingga seseorang yang memiliki pengalaman sedikit belum tentu mereka memiliki pengetahuan yang sedikit pula.
Pengaruh Usia terhadap Pengetahuan Akuntansi UMKM

Berdasarkan total jawaban kuesioner untuk Variabel $\mathrm{X}_{6}$ (Usia) dari 100 responden didapat bahwa usia para pelaku UMKM Kab. Subang didominasi pada usia < 41 tahun dengan persentase sebesar 58\%, diikuti oleh usia 41 - 60 tahun sebesar $36 \%$ dan usia $>60$ tahun sebesar $6 \%$. Pada penelitian ini tidak membuktikan adanya pengaruh usia terhadap pengetahuan Akuntansi UMKM sejalan dengan hasil penelitian Debbianita \& Dewi N. S. (2016) hasil penelitian menunjukkan bahwa tidak terdapat perbedaan tingkat pengetahuan pelaku UMKM mengenai SAK ETAP pada kategori usia.

Hasilnya dapat dilihat pada uji statistik t yang menunjukan bahwa nilai signifikansi lebih besar dari 0,05 yaitu 0,982 yang berarti $\mathrm{H}_{6}$ ditolak. Jadi Usia tidak berpengaruh terhadap Pengetahuan Akuntansi UMKM. Hal tersebut bisa terjadi karena reponden yang peneliti ambil secara random didominasi oleh tingkat usia < 41 tahun, tingkatan usia tidak mempengaruhi pengetahuan bisa disebabkan karena kebutuhan 
mengenai pengetahuan Akuntansi UMKM tidak memandang usia, usia lebih muda ternyata lebih menyadari pentingnya pengetahuan mengenai Akuntansi UMKM dibandingkan usia yang lebih dewasa yang merasa belum terlalu membutuhkan informasi mengenai Akuntansi UMKM, dan dalam kategori usia produktif maka usia yang lebih muda lebih produktif dibandingkan dengan usia lebih dari 41 tahun.

\section{Pengaruh}

Pendidikan, Informasi/Media Massa, Lingkungan Sosial dan Lingkungan Budaya, Ekonomi, Pengalaman, dan Usia secara Simultan terhadap Pengetahuan Akuntansi UMKM

Berdasarkan total jawaban kuesioner untuk pengaruh variabel secara simultan dari 100 responden menyatakan bahwa terdapat pengaruh pendidikan, informasi/media massa, lingkungan sosial dan lingkungan budaya, ekonomi, pengalaman dan usia secara simultan terhadap tingkat pengetahuan Akuntansi UMKM pada pelaku UMKM. Hal itu dibuktikan melalui uji statistik $f$ yang menunjukkan bahwa nilai $F$ sebesar 8,565 dan $F$ tabel $=2,200$ karena $F$ hitung $>F$ tabel artinya pendidikan, informasi/media massa, lingkungan sosial dan lingkungan budaya, ekonomi, pengalaman dan usia secara simultan berpengaruh signifikan terhadap tingkat pengetahuan Akuntansi UMKM. Hal tersebut disebabkan faktor-faktor tersebut jika digunakan bersama-sama akan sangat menambah pengetahuan seseorang.

\section{KESIMPULAN}

Dari beberapa pengujian yang telah dilakukan dalam penelitian ini dapat diambil kesimpulan bahwa:

1. Terdapat pengaruh pendidikan terhadap tingkat pengetahuan Akuntansi UMKM pada pelaku UMKM. Faktor pendidikan tidak dapat dijadikan penentu untuk melihat tingkat pengetahuan yang dimiliki oleh pelaku UMKM. Hal tersebut bisa terjadi karena Pendidikan mempengaruhi proses belajar, makin tinggi pendidikan seorang makin mudah orang tersebut untuk menerima informasi dalam hal pengetahuan mengenai akuntansi.

2. Tidak terdapat pengaruh informasi/media massa terhadap tingkat pengetahuan Akuntansi UMKM pada pelaku UMKM. Faktor 
informasi/media massa tidak dapat dijadikan penentu untuk melihat tingkat pengetahuan yang dimiliki oleh pelaku UMKM. Hal itu disebabkan kesibukan pelaku UMKM maka minat responden untuk menggali lebih banyak informasi mengenai akuntansi itu masih sedikit, sehingga mereka hanya menyempatkan menggali informasi mengenai akuntansi dengan mengkonsumsi 1 informasi/media massa saja yakni internet.

3. Terdapat pengaruh lingkungan sosial dan lingkungan budaya terhadap tingkat pengetahuan Akuntansi UMKM pada pelaku UMKM. Faktor lingkungan sosial dan lingkungan budaya dapat dijadikan penentu untuk melihat tingkat pengetahuan yang dimiliki oleh pelaku UMKM. Hal ini disebabkan karena lingkungan adalah tempat seseorang beraktifitas seharihari sehingga informasi akan sangat mudah menyebarkan di sekitarnya, dan menyebabkan informasi akan mudah diserap oleh seseorang melalui penjelasan langsung atau yang disebut mulut ke mulut.

4. Terdapat pengaruh ekonomi terhadap tingkat pengetahuan Akuntansi
UMKM pada pelaku UMKM. Faktor ekonomi dapat dijadikan penentu untuk melihat tingkat pengetahuan yang dimiliki oleh pelaku UMKM. Hal ini disebabkan karena dengan ekonomi merupakan salah satu faktor penting dalam menunjang kehidupan sehari-hari. Dengan memiliki perekonomian yang cukup atau lebih maka seseorang akan mudah memiliki fasilitas untuk menggali informasi lebih banyak pula.

5. Tidak terdapat pengaruh pengalaman terhadap tingkat pengetahuan Akuntansi UMKM pada pelaku UMKM. Faktor pengalaman tidak dapat dijadikan penentu untuk melihat tingkat pengetahuan yang dimiliki oleh pelaku UMKM. Hal tersebut bisa terjadi karena pengalaman usaha yang mereka miliki masih baru dan latar belakang keluarga mereka bukan pengusaha, sehingga pengetahuan yang mereka miliki masih sedikit. Hal itulah yang menjadi pemicu mereka untuk menggali informasi lebih banyak. Sehingga seseorang yang memiliki pengalaman sedikit belum tentu mereka memiliki pengetahuan yang sedikit pula. 
6. Tidak terdapat pengaruh usia terhadap tingkat pengetahuan Akuntansi UMKM pada pelaku UMKM. Faktor usia tidak dapat dijadikan penentu untuk melihat tingkat pengetahuan yang dimiliki oleh pelaku UMKM. Hal itu disebabkan bisa terjadi karena reponden yang peneliti ambil secara random didominasi oleh tingkat usia $<$ 41 tahun, barangkali seseorang yang memiliki usia lebih muda ternyata lebih menyadari pentingnya pengetahuan mengenai Akuntansi UMKM dibandingkan usia yang lebih dewasa yang merasa belum terlalu membutuhkan informasi mengenai Akuntansi UMKM, dan dalam kategori usia produktif maka usia yang lebih muda lebih produktif dibandingkan dengan usia lebih dari 41 tahun.

Terdapat pengaruh pendidikan, informasi/media massa, lingkungan sosial dan lingkungan budaya, ekonomi, pengalaman dan usia secara simultan terhadap tingkat pengetahuan Akuntansi UMKM pada pelaku UMKM. Hal itu dibuktikan melalui uji statistik $\mathrm{f}$ yang menunjukkan bahwa nilai $\mathrm{F}$ sebesar 8,565 dan $\mathrm{F}$ tabel $=2,200$ karena $\mathrm{F}$ hitung $>\mathrm{F}$ tabel artinya pendidikan, informasi/media massa, lingkungan sosial dan lingkungan budaya, ekonomi, pengalaman dan usia secara simultan berpengaruh signifikan terhadap tingkat pengetahuan Akuntansi UMKM. Hal tersebut disebabkan faktorfaktor tersebut jika digunakan bersamasama akan sangat menambah pengetahuan seseorang. 